\title{
7th Grade Students' Understandings of Negative Integer
}

\author{
Alattin Ural \\ Dept. of Mathematics Education, Faculty of Education, Mehmet Akif Ersoy University \\ Burdur 15100, Turkey
}

Tel: 90-248-213-4024Ｅ-mail: altnurl@gmail.com

\author{
Received: Feb. 22, 2016 Accepted: April 10, 2016 Published: May 15, 2016 \\ doi:10.5296/jse.v6i2.9075 URL: http://dx.doi.org/10.5296/jse.v6i2.9075
}

\begin{abstract}
The aim of the research is to determine $7^{\text {th }}$ grade students' understandings relating the concept of negative integer. For this purpose, a total of $1007^{\text {th }}$ grade students who were selected randomly from 4 middle school in Burdur centre were asked those two questions: "what do negative integers mean, where do they use", "write a problem appropriate for the expression of " $+3-7=-4$ ". The research is a qualitative research and the model is general scanning model. Descriptive analysis was conducted in analysis of the data. The students' responses were tried to be given directly and presented categorically. The students indicated commonly the contexts of "temperature below 0 degree", altitude below sea level (minus elevation)" and "debt" as usage areas of the negative integers. $38 \%$ of the students couldn't give any example for usage areas of the negative integers. $22 \%$ of the students couldn't write a problem appropriate for the given expression. These students indicated inappropriate context or inappropriate problem mathematically. $45 \%$ of the students didn't write any problem. As a result, $67 \%$ of the students couldn't write an appropriate problem. $33 \%$ of the students could write problems that are considered as appropriate. These students used commonly the contexts of "dept, dept owed, lose money".
\end{abstract}

Keywords: Education, Mathematics education, Mathematics lessons, Achievement, Affective factors. 


\section{Introduction}

The concept of negative number and operations with integers hold some conceptual difficulties (Ardahan \& Ersoy, 1997; 1998; Altınok, Keşan \& Y1lmaz, 2005; Bishop, Lamb, Philipp, Whitacre, Schappelle \& Lewis, 2014; Kinach, 2002; Vlasis, 2001) and these difficulties can affect negatively the process of learning some important algebraic concepts such as algebraic expressions and equation. Vlasis (2001) indicated that students' misconceptions about integers caused difficulties in algebra. Research shows that negative numbers create difficulties for students as they try to make sense of them (Gallardo, 2002; Gallardo \& Romero, 1999; Peled, Mukhopadhyay \& Resnick, 1989). Kinach (2002) observed that many preservice teachers hold an instrumentalist view of mathematics, and therefore they couldn't justify the meaning of the procedures. Melemezoğlu (2005) determined that the students had difficulties and misconceptions about the subjects of operations, word problems and producing a model with integers. Avcu and Durmaz (2011) revealed that the students had difficulties about ordering the integers and doing operations with integers.

Various researches that focused specifically on number and operations conflict in terms of what students understand about negative numbers across the grades were conducted (Aze, 1989; Bishop, Lamb, Phillip, Schapelle, \& Whitacre, 2011; Hativa \& Cohen, 1995; Mukhopadhyay, 1997; Murray, 1985; Peled, Mukhopadhyay \& Resnick, 1989; Thompson \& Dreyfus, 1988; Whitacre et al. 2012a; Wilcox, 2008). Also, many studies have investigated the ways that improve students' understanding of integers. These studies used different models which can be categorized mainly in two groups: neutralization model and number line model. While the neutralization models use physical objects such as colored chips or tiles to represent positive and negative numbers and show the operations by manipulating them, number line models represent the operation by the direction of movement along the line and the numbers located based on its position and the distance (Lytle, 1994). There have been many studies that used neutralization models. While some of these studies used abacus as a concrete model for representing operations with integers (Dirks, 1984; Linchevski \& Williams, 1999), others used algebra tiles to represent positive and negative numbers with differently colored squares (Maccini \& Ruhl, 2000), models based on collections of electromagnetic charges (Battista, 1983) and a helium-filled balloon model (Janvier,1983). For the number line model Thompson and Dreyfus (1988) used computer microworld to teach integers. Addition to those models, the subject of integers has been dealt with in the real life context as well such as temperature, debt, profit, cost and altitude. Bozkurt and Polat (2011) stated that the teachers did not use other models or materials except from colored chips while teaching the integers. As a reason, they specified that the teachers did not have adequate information about the other methods of modelling and real life problems.

Bishop, Lamb, Philipp, Whitacre and Schappelle (2014) revealed that students had intuitive ideas about negative numbers prior to school based instruction. Akyüz, Stephan and Dixon (2012) attempted to document and demonstrate the role of an expert middle school mathematics teacher in helping students develop meaningful imagery during the instruction of the concepts of integers and integer addition and subtraction. The findings revealed that various situation-specific and notational images that students developed during the instruction 
of the integers helped them understand and solve the mathematical problems meaningfully. This study demonstrated that imagery could be supported by first designing a learning trajectory which includes a supportive context, tools to be used, notations to be developed, and learning goals to be achieved.

Bofferding (2014) tried to detail first graders' mental models of negative integers and to investigate how instruction on the binary and/or unary meanings of the minus sign supports or constrains their thinking about negative integers. Students in this study exhibited a range of integer understanding that highlights important conceptual changes the first graders had to overcome before developing formal mental models. Resnick (1983), Peled et al. (1989) concluded that the students relied on a number line mental model to support their thinking about negative integers. They found that students either used a Divided Number Line model, where students calculate to and from the zero point and interpret the positive and negative halves as separate, or a Continuous Number Line model, allowing students to move easily between positive and negative numbers. Peled (1991) later expounded that students' integer descriptions are consistent with them having one or two types of mental models: one regarding quantities, where negative numbers are considered to be unfavourable amounts, such as debts, where the larger the unfavourable amount, the smaller the number and one regarding a number line where negative numbers are abstract entities ordered to the left of zero, with larger values ordered further to the right. For both mental models, Peled (1991) described four levels of understanding: students at the first level of integer knowledge know the order of all integers, with larger numbers further to the right on the number line and the numerals ordered symmetrically around zero; at the second level, students can add positive numbers to any integer; at the third level, students can add or subtract two positive or two negative numbers; and at the fourth level, students can add or subtract any two integers. The number line model highlights the order of negative numbers compared to positive numbers, and number values can be interpreted as distances from zero in opposite directions, providing meaning for the unary meaning of the minus sign and directed magnitudes. Fischbein (1977) and Freudenthal (1973) agreed that number line models could be helpful for supporting integer addition, and the National Council of Teachers of Mathematics (2000) recommends students use a number line model to explore numbers less than zero. Further, Hativa and Cohen (1995) found that fourth graders could successfully compare integers after completing an intervention where they made computations to reach a target integer and received visual feedback of their calculations on a number line model.

Köroğlu and Yeşildere (2004) investigated the effect of the multiple intelligences theory based teaching in the unit of whole numbers on learner achievement. As a result, they revealed that the students could not recognize the relation and difference the operations of addition and subtraction with integers completely; on the other hand, they concluded that the method used in the research was effective. In the result of the research by Akyüz (2012), it was determined that the middle school students were able to deal with the integer problems in the context of profit-loss using the model of vertical number line. Kutluca and Akin (2013) prepared some learning activities on the basis of the method of discovering learning using four-quadrant algebraic weight scales as concrete material in the instruction of whole 
numbers unit. As a result of the research, they indicated that the materials were appropriate for comparing integers, finding reverse integer according to addition and modelling an equality containing integers. Şengül and Dereli (2013) concluded that the instruction of integer using cartoons was more effective in terms of achievement and retention than traditional learning.

\section{Method}

The aim of the research is to determine $7^{\text {th }}$ grade students' understandings relating the concept of negative integer. For this purpose, a total of $1007^{\text {th }}$ grade students who were selected randomly from 4 middle school from Burdur Province of Turkey were asked those two questions: "what do negative integers mean, where do they use", "write an appropriate problem for the expression of $+3-7=-4$ ". The research is a qualitative research and the model is general scanning model. Descriptive analysis was conducted in analysis of the data.

\section{Results}

\subsection{Results Related the $1^{\text {st }}$ Question}

The students were asked what do negative integers mean and where do they use. The responses were presented in Table 1 and Table 2.

Table 1. Meaning of the negative integers according to the students

\begin{tabular}{ll}
\hline Meaning & Frequency \\
\hline Minus numbers & $34(43 \%)$ \\
Numbers that are less than zero & $25(32 \%)$ \\
Negative situations & $6(8 \%)$ \\
Loss-making & $4(5 \%)$ \\
The numbers that are on the left side & $3(4 \%)$ \\
of zero & \\
Harmful numbers & $2(3 \%)$ \\
Decrease & $2(3 \%)$ \\
Small numbers & $2(3 \%)$ \\
Subnormal & $1(1 \%)$ \\
\hline Total & $79(100 \%)$ \\
\hline
\end{tabular}

From the Table 1, it was seen that the students understand generally the negative integers as "minus numbers" or "the numbers that are less than zero" from. It was understood from those responses that the students gave directly mathematical meaning of the negative integers. A few students reflected their subjective understandings. These students attributed some meanings such as "harmful numbers", "decrease" and "subnormal" to negative integers. $21 \%$ of the students didn't indicate what they understood related negative numbers. 


\section{Macrothink}

Table 2. The students' usage areas of negative integers

\begin{tabular}{ll}
\hline Meaning & Frequency \\
\hline Indicating the temperature below zero & $43(46 \%)$ \\
Indicating the minus elevation & $21(23 \%)$ \\
Indicating the situation of debt & $12(13 \%)$ \\
Indicating the situation of loss & $7(8 \%)$ \\
Indicating the distance of going back & $4(4 \%)$ \\
Indicating the expenses & $2(2 \%)$ \\
Indicating the floors below the ground floor & $2(2 \%)$ \\
Indicating the dug distance & $1(1 \%)$ \\
Indicating the contrary situations & $1(1 \%)$ \\
\hline Total & $93(100 \%)$ \\
\hline
\end{tabular}

A total of $62(62 \%)$ students were able to give at least one example for usage area of negative integers. Totally 93 examples were given and it was stated commonly that negative integers could be used in the context of "temperature", "minus elevation" and "debt". $38 \%$ of the students couldn't give an example for usage area of negative integers.

\subsection{Results Related the $2^{\text {nd }}$ Question}

The students were asked to write an appropriate problem to the expression " $+3-7=-4$ ". The responses were given categorically in terms of suitability.

\subsubsection{Inappropriate problems (22 students)}

Use for the variables that have an absolute zero such as age and amount (9 students)

- I had 3 Turkish Lira (TL), gave 7 TL of it, how much did it remain? (4 students)

- I had $3 \mathrm{~kg}$ of apple, $7 \mathrm{~kg}$ of them fell, how many $\mathrm{kg}$ of apple remained?

- I had 3 balls, 7 of them got lost, and how many did it remain?

- I have 3 pencils, if I give 7 of them, how many pencils do I have now?

- Ayşe is 7 years older than Ahmet. When Ayşe was 3, how old was Ahmet?

- Ali has 3 apples and Ahmet has 7 apples. How many apples does Ali has lesser than Ahmet?

Writing a mathematical problem directly without indicating a problem situation (3 students)

- It is $3^{\circ}$ in Burdur and $-7^{\circ}$ in Van. What is the total temperature? (2 students)

- If It is $7^{\circ}$ daytime and $3^{\circ}$ night time then what is temperature difference?

Writing the expression of question wrongly or not writing (6 students).

- Temperature increased $3^{\circ}$ then decreased $7^{\circ}$ what is it now? ( 2 students)

- I am on the $3^{\text {rd }}$ floor of the earth. I came down -7 floors. Where am I? 
- I have 3 TL and 7 TL debt (2 students)

- I have 3 apples, 7 of my friends came and gave 3 apples to them. Which sign can be used for the remaining apples?

Others (4 students)

- It is $3^{\circ}$ in Burdur and $-7^{\circ}$ in Van. What is temperature difference?

- I have 7 balls, I lost 3 of them, and how many did it remain?

- I have 3 apples, my father wants 4 apples, and how many more apples must I bring?

- I am jumping from 3 meters of altitude into 7 meters of water. What is my depth?

4.2.2 Appropriate problems (33 students)

Use for the variables that have not an absolute zero such as altitude and temperature (2 students)

- I am over 3 meters of sea, went down 7 meters, where am I?

- Temperature was $3^{\circ}$ then decreased $7^{\circ}$ what is it now?

Indicating the value of the variables that can be considered negative such as debt owed, money owed and loss with the symbol “_“ (31 students)

- $\quad$ I had 7 TL debts, paid 3 TL of it, how much do I have debt? (9 students)

- I have 7 TL debt and 3 TL debt owed. How much do I have debt? (5 students)

- I had 3 TL, did shopping of 7 TL. How much do I have debt? (4 students)

- I have $3 \mathrm{TL}$ and $7 \mathrm{TL}$ of debt. How much more must I pay? (-4 means the money to be paid) (3 students)

- I have 3 TL and 7 TL of debt. What is the result?

- I have 3 credits in my phone, talked 7 credits, how many credits do I have remained? (4 students)

- 7 persons were hungry, 3 of them were full, and how many hungry persons are there? (to be hungry was qualified as a negative situation and symbolized with "_.“.

- There are $3 \mathrm{~kg}$ of apples in grocery, asked $7 \mathrm{~kg}$, he gave $3 \mathrm{~kg}$ of it. How many $\mathrm{kg}$ of apples remained?

- I bought something for $7 \mathrm{TL}$ and sold for $3 \mathrm{TL}$. What is my gain or loss situation?

- I gained 3 TL and lost 7 TL from a deal. What is my gain or loss situation?

- I gave 7 candies to my friend and got 3 candies. What is my gain or loss situation? 


\section{Conclusion}

The students indicated commonly the contexts of "temperature below 0 degree", "altitude below sea level (minus elevation)" and "debt" as usage areas of the negative integers. $38 \%$ of the students couldn't give any example for usage areas of the negative integers. $22 \%$ of the students couldn't write a problem appropriate for the given expression. These students indicated inappropriate context or inappropriate problem mathematically. $45 \%$ of the students didn't write any problem. As a result, $67 \%$ of the students couldn't write an appropriate problem. $33 \%$ of the students could write problems that are considered as appropriate. These students used commonly the contexts of "dept, debt owed, lose money". In their research, Avcu and Durmaz (2011) concluded that only 15\% of the 267 sixth and seventh grade students were able to pose a problem based on (1) $-18: 6=-3$ and (2) $-26+(-3)=-29$. Peled and Carraher (2006) revealed that most preservice teachers (9 of 15; 9 of the 12 who gave answers) used a money/debt context for the expression, " $2-7=$ ".

School students were found to have difficulties in understanding concept of negative numbers (e.g., Janvier, 1983; Hativa \& Cohen, 1995). The main sources of these difficulties are (quoted in Hativa \& Cohen, 1995): (a) the conflict between the practical meaning of magnitude or quantity associated with numbers in early arithmetic teaching, and the concept of negative numbers (Fischbein, 1987; Hefendehl-Hebeker, 1991); (b) The conflict between the two different meanings of the sign "-“ (Janvier, 1985; Carraher, 1990); and (c) The absence of a good, intuitive, familiar model which would consistently satisfy all the algebraic properties of signed numbers (Glaeser, 1981). Vlassis (2002a, 2004) examined how middle school students interpreted negativity and found that eighth-grade students conceptualized negativity as a process linked to the binary operation of subtraction. She concluded that the different uses of the negative sign are counterintuitive and an obstacle for students. Similarly, Gallardo (2002), Gallardo and Romero (1999) stated that researches showed that integers, especially negative numbers, created difficulties for students as they tried to make sense of them based on their presuppositions about natural numbers and assume that what they knew about natural numbers holds for integers.

\section{References}

Akyüz, D. (2012, June). Ortaokul Öğrencilerinin Tamsayılar Konusundaki Çözüm Stratejileri. X. Ulusal Fen Bilimleri ve Matematik Eğitimi Kongresi, Niğde.

Akyüz, D., Stephan, M., \& Dixon, J. K. (2012). The Role of the Teacher in Supporting Imagery in Understanding Integers, Education and Science, 37(163), 268-282.

Altınok, A., Keşan, C., \& Yılmaz, S. (2005, September). İlköğretim 7. Sınıf Tamsayılar Konusunun Günlük Yaşamla İlişkilendirilmesi ve Öğrenci Üzerindeki Etkisi. XIV. Ulusal Eğitim Bilimleri Kongresi Pamukkale Üniversitesi.

Ardahan H., \& Ersoy Y. (1997). Deficiencies in Solving Problems with Directed Numbers in Secondary Schools", Europen Research Conference on Mathematics Education (ERCME'97 31 Aug-4 Sep. Czech Republic, Podebrary. 
Avcu, T., \& Durmaz, B. (2011, April). Tam sayılarla ilgili işlemlerde ilköğretim düzeyinde yapılan hatalar ve karşılaşılan zorluklar. 2nd International Conference on New Trends in Education and Their Implications. 27-29 April, Antalya-Turkey.

Aze, I. (1989). Negatives for little ones? Mathematics in School, 18(2), 16-17.

Bishop, J. P., Lamb, L. L., Philipp, R. A., Whitacre, I., Schappelle, B. P., \& Lewis, M. L. (2014). Obstacles and Affordances for Integer Reasoning: An Analysis of Children's Thinking and the History of Mathematics. Journal for Research in Mathematics Education, 45(1), 19-61. http://dx.doi.org/10.5951/jresematheduc.45.1.0019

Bishop, J. P., Lamb, L. L., Philipp, R. A., Schapelle, B. P., \& Whitacre, I. (2011). First graders outwit a famous mathematician. Teaching Children Mathematics, 17(6), 350-358.

Bishop, J. P., Lamb, L. L., Philipp, R. A., Whitacre, I., \& Schappelle, B. P. (2014). Using order to reason about negative numbers: the case of Violet. Educ Stud Math, 86, 39-59. http://dx.doi.org/10.1007/s10649-013-9519-x

Bofferding, L. (2014). Negative integer understanding: Characterizing first graders' mental models. Journal for Research in Mathematics Education, 45(2), 194-245. http://dx.doi.org/10.5951/jresematheduc.45.2.0194

Bozkurt, A., \& Polat, M. (2011). Sayma Pullarıyla Modellemenin Tam Sayılar Konusunu Öğrenmeye Etkisi Üzerine Öğretmen Görüşleri, Gaziantep Üniversitesi Sosyal Bilimler Dergisi, 10(2), 787 -801.

Dirks, M (1984). The integer abacus. Arithmetic Teacher, 31(7), 50-54.

Fischbein, E. (1977). Image and concept in learning mathematics. Educational Studies in Mathematics, 8(2), 153-165. http://dx.doi.org/10.1007/BF00241022

Freudenthal, H. (1973). Mathematics as an educational task. Dordrecht, Holland: D. Reidel.

Gallardo, A., \& Romero, M. (1999). Identification of difficulties in addition and subtraction of integers in the number line. In F. Hitt, \& M. Santos (Eds.), Proceedings of the Twenty-first International Conference for the Psychology of Mathematics Education (Vol. I. pp. 275-282). North American Chapter, Mexico.

Gallardo, A. (2002). The extension of the natural-number domain to the integers in the transition from arithmetic to algebra. Educational Studies in Mathematics, 49, 171-192. http://dx.doi.org/10.1023/A:1016210906658

Hativa, N., \& Cohen, D. (1995). Self-learning of negative number concepts by lower division elementary students through solving computer-provided numerical problems. Educational Studies in Mathematics, 28(4), 401-431. http://dx.doi.org/10.1007/BF01274081

Janvier, C. (1983). The understanding of directed number. In J. C. Bergeron \& N. Herscovics (Eds.), Proceedings of the Fifth Annual Meeting of the North American Chapter of the International Group for the Psychology of Mathematics Education (Vol. 2, pp. 295- 301). Montreal: Universite de Montreal. 
Kinach, B. M. (2002). A cognitive strategy for developing pedagogical content knowledge in the secondary mathematics methods course: toward a model of effective practice. Teaching and Teacher Education, 18(1), 51-71. http://dx.doi.org/10.1016/S0742-051X(01)00050-6

Köroğlu, H., \& Yeşildere, S. (2004). Learner Achievement Effect of the Multiple Intelligences Theory Based Teaching in the Unit of Whole Numbers at the Primary Education Seventh Grade Mathematics Course. Gazi Üniversitesi, Gazi Eğitim Fakültesi Dergisi, 24(2), $25-41$.

Kutluca, T., \& Akın, M. F. (2013). Teaching of Mathematics with Concrete Materials: Qualitative Study on Using Four-Quadrant Algebraic Scales. Turkish Journal of Computer and Mathematics Education, 4(1), 48-65.

Linchevski, L., \& Williams, J. D. (1999). Using intuition from everyday life in "filling" the gap in children's extension of their number concept to include the negative numbers. Educational Studies in Mathematics, 39, 131-147. http://dx.doi.org/10.1023/A:1003726317920

Lytle, P. (1994). Investigation of a Model Based on the Neutralization of Opposites to Teach Integer Addition and Subtraction. In Proceedings of the 18th International Group for the Psychology of Mathematics Education, 3, 192-199), Concordia University, West Montreal, Canada.

Maccini, P., \& Ruhl, K. L. (2000). Effects of a graduated instructional sequence on the algebraic subtraction of integers by secondary students with learning disabilities. Education and Treatment of Children, 23, 465-489.

Melemezoğlu, Ç. (2005). A research on mistakes and misconceptions of the students in teaching direct numbers (Unpublished Master Thesis). Selçuk University, Konya.

Mukhopadhyay, S. (1997). Story telling as sense-making: Children's ideas about negative numbers. Hiroshima Journal of Mathematics Education, 5, 35-50.

Murray, J.C. (1985). Children's informal conceptions of integer arithmetic. In L. Streefland (Ed.), Proceedings of the Ninth Annual Conference of the International Group for the Psychology of Mathematics Education (Vol. 1, pp. 147-153). Noordwijkerhout, the Netherlands.

National Council of Teachers of Mathematics. (2000). Principles and standards for school mathematics. Reston, VA.

Peled, I., \& Carraher, D. W. (2006). Signed Numbers and Algebraic Thinking. Kaput Chapter, 12, 303-328.

Peled, I., Mukhopadhyay, S., \& Resnick, L. B. (1989). Formal and informal sources of mental models for negative numbers. In G. Vergnaud, J. Rogalski, \& M. Artique (Eds.), Proceedings of the 13th Annual Conference of the International Group for the Psychology of Mathematics Education (Vol. 3, pp. 106-110). Paris, France. 


\section{Macrothink}

Journal of Studies in Education

ISSN 2162-6952 2016, Vol. 6, No. 2

Peled, I. (1991). Levels of knowledge about signed numbers: Effects of age and ability. In F. Furinghetti (Ed.), Proceedings of the 15th Annual Meeting of the International Group for the Psychology of Mathematics Education (Vol. 3, pp. 145-152). Assisi, Italy.

Resnick, L. B. (1983). A developmental theory of number understanding. In H. P. Ginsburg (Ed.), The development of mathematical thinking (pp. 109-151). New York, NY: Academic Press.

Şengül, S. \& dereli, M. (2013). The effects of teaching integers using cartoons on 7 th grade students' achievements and retention levels. International Journal of Social Science, 6(7), 973-1003.

Thompson, P. W., \& Dreyfus, T. (1988). Integers as transformations. Journal for Research in Mathematics Education, 19(2), 115-133. http://dx.doi.org/10.2307/749406

Vlassis, J. (2001). Solving equations with negatives or crossing the formalizing gap. In M. Van den Heuvel-Panhuizen (Ed.), Proceedings of the twenty-fifth international conference for the psychology of mathematics education (Vol. 4, pp. 375-382). Utrecht, Netherlands.

Whitacre, I., Bishop, J. P., Lamb, L. C., Philipp, R. A., Schappelle, B. P., \& Lewis, M. L. (2012). Happy and sad thoughts: An exploration of children's integer reasoning. Journal of Mathematical Behavior, 31(3), 356-365. http://dx.doi.org/10.1016/j.jmathb.2012.03.001

Wilcox, V. (2008). Questioning zero and negative numbers. Teaching Children Mathematics, 15(4), 202-206. 